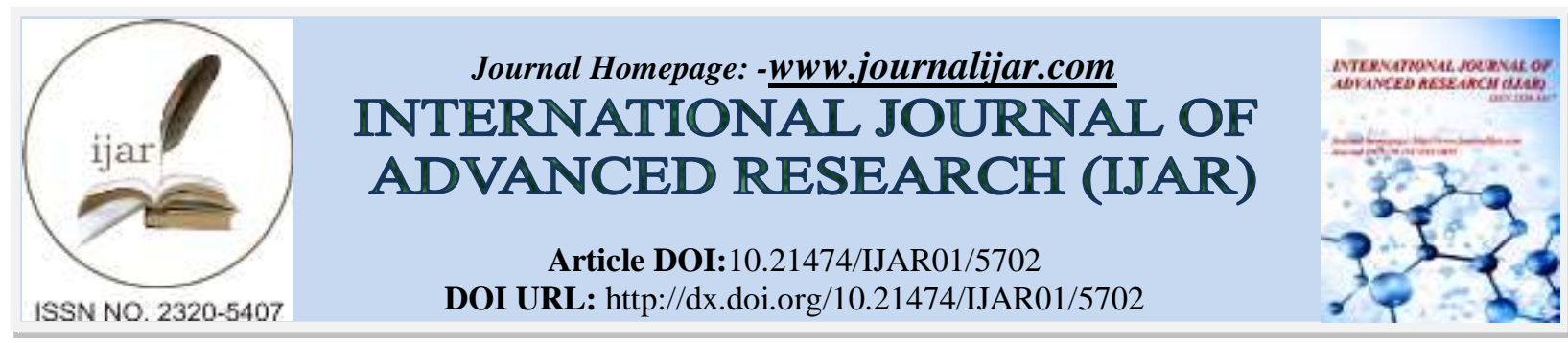

RESEARCH ARTICLE

\title{
HEAVY METAL BIOSORPTION POTENTIAL OF PSEUDOMONAS SP. ISOLATED FROM INDUSTRIAL WASTEWATER OF HARIDWAR DISTRICT, INDIA.
}

\begin{abstract}
Namitajoshi, Deep gupta and Anubala.
1. Department of Environment science, KanyaGurukulcampus ,Haridwar India.

2. Department of civil engineering, COER.
\end{abstract}

\section{Manuscript Info}

Manuscript History

Final Accepted: 25 September 2017

Published: October 2017
Received: 23 August 2017

\begin{abstract}
The present study was done to evaluate the heavy metal biosorption potential of two bacterial strains isolated from industrial wastewater of Haridwar industrial area. The wastewater samples were collected from four different sites., i.e., HI, BI, OD and DI. The heavy metal concentrations were determined after digestion of wastewater samples. The heavy metal resistant bacteria were isolated and screened for their Biosorption potential. The minimum inhibitory concentration (MIC) of $\mathrm{Pb}, \mathrm{Cr}, \mathrm{Ni}$ and $\mathrm{Zn}$ was determined by agar diffusion method in 25, 50, $100,200 \& 400 \mathrm{ppm}$ concentrations. The isolates were identified and characterized molecularity with $16 \mathrm{~S}$ rRNA gene sequence analysis and were revealed 99\% similarities of BIN and BOD with Pseudomonas geniculate and Pseudomonas hibiscocola respectively. Biosorption experiments indicate that, BIN and BOD strain could bioadsorb metals in the order $\mathrm{Pb}>\mathrm{Cr}>\mathrm{Zn}>\mathrm{Ni}$ and $\mathrm{Ni}>\mathrm{Cr}>\mathrm{Pb}>\mathrm{Zn}$.
\end{abstract}

Copy Right, IJAR, 2017,. All rights reserved.

\section{Introduction:-}

The quality of life on earth is linked inextricable to the overall quality of the environment. The development or new inventions in different fields like astronomical, medical, agricultural, corporate, engineering etc are serving human living too easy in present days. Human activities are intimately tied to the environment and bio-friendly behavior of human beings often has harmful consequences on environment. With the rapid development of industries heavy metal pollution has become one of the most serious environmental problems. Heavy metals affect many biological processes such as respiration, photosynthesis, reproduction and metabolism which cause a partial or total damage to living organisms ${ }^{1,2}$. Both natural and anthropogenic activities are responsible in accumulation of wide ranges of toxic heavy metals in environment and thus global concern. Contaminants vary in their tendency to end up in water held in the soil or in the underlying ground water (by leaching through the soil), volatize (evaporate) into the air and binding tightly to the soil ${ }^{3}$. The fates and behavior of heavy metals are controlled by process of sinks and processes of remobilization addressing as entering compartment ${ }^{4}$. The process of sinks consist of adsorption and coprecipitation, precipitation and incorporation in biological activity and the process of remobilization comprise elevated salt concentration, changes in redox reaction, lowering of $\mathrm{pH}$, increasing use of organic complexing agents and biochemical process. The search for new and innovative technology for the remediation of heavy metals pollution has attracted the attention on the biosorption potential of certain micro-organism. The use of microbial biomass like bacteria, fungi, algae and yeast as a Biosorbent is a potential alternative over chemical methods for removal of metals from soil and industrial wastewater by the method known as biosorption. Biosorption is a passive removal of metals using non-living biomass as adsorbent material which is metabolism-independent, in contrast to 
bioaccumulation i.e., metabolism dependent process $^{5}$.. It is a property of certain types of inactive, non-living microbial biomass to bind and concentrate heavy metals from very dilute aqueous solution. It is particularly the cell wall structure of certain bacteria, algae and fungi, which was found responsible for the biosorption ${ }^{6}$. The main mechanism of biosoption include mechanism of absorption, ion-exchange, surface complexion and precipitation ${ }^{7}$. Bacteria and fungi used across various industries (e.g., Nutritional, Pharmaceutical ) become post production waste that may be valuable, free of cost Biosorbent. Potent metal biosorbents among bacteria include genera Bacillus, Pseudomonas, Streptomyces, Micrococcus and Escherichia coli. In the present study two Pseudomonas sp. were isolated from industrial wastewater sample and further evaluated for biosorption capacity of Lead, Chromium, Nickel and Zinc in laboratory experiment

\section{Material and Methods:- \\ Sampling:-}

Industrial wastewater samples were collected from four dufferent sited i.e., Haridwar industrial area (HI), Bahadrabad Industrial area (BI), Open drainage of SIDCUL (OD) and direct effluent (DI). The samples were collected in sterile bottles and stored at $4^{\circ} \mathrm{C}$ in the refrigerator to prevent volume change due to evaporation.

\section{Heavy metal analysis of wastewater samples:-}

Samples were digested by taking $20 \mathrm{ml}$ of sample in $100 \mathrm{ml}$ glass beaker. $10 \mathrm{ml}$ of nitric acid and $5 \mathrm{ml}$ of perchloric acid were added to sample and evaporated on hot plate for $2 \mathrm{hrs}$ by slow boiling. After evaporation to near $10-20$ $\mathrm{ml}$, the samples were dissolved with $10 \mathrm{ml}$ nitric acid, filtered and diluted to $50 \mathrm{ml}$ with distilled water. Total metal concentration $(\mathrm{Cr}, \mathrm{Ni}, \mathrm{Co}, \mathrm{Cu}, \mathrm{Fe}, \mathrm{Cd}, \mathrm{Pb}$ and $\mathrm{Zn})$ of digested samples were analysed by using $\mathrm{AAS}^{8}$.

Enumeration and Identification of heavy metal resistant bacteria species:-

Wastewater samples were serially diluted upto $10^{-5}$ and were spread on Nutrient agar plates enriched with $25 \mathrm{ppm}$ of heavy metal $(\mathrm{Pb}, \mathrm{Zn}, \mathrm{Cr} \& \mathrm{Ni})$ individually incubated at $37^{\circ} \mathrm{C}$ for $24 \mathrm{hr}^{9}$. After incubation, colony forming unit of each plate was calculated and according to morphology, bacterial isolates were purified further by streaking on nutrient agar plate. Bacterial isolates were maintained on agar slants. The minimum inhibitory concentration (MIC) of isolates at which no growth occurred was determined by agar diffusion method ${ }^{10}$. The concentration range was 25 $\mathrm{ppm}$ to $400 \mathrm{ppm}$. According to MIC, the two bacterial isolates were identified by Gram's staining and some biochemical test such as Indole test, Methyl red (MR) and Voges- proskeur etc.

The molecular characterization of selected isolates was done by $16 \mathrm{~S}$ sequence analysis. The bacterial genomic DNA was extracted using standard protocol ${ }^{11}$. the strains were amplified by PCR using two bacterial $16 \mathrm{~S}$ primers, 5'AGAGTTGATCMTGGCTCA-3' (27F) for forward sequencing and 5'-CGGTTACCTTGTTACGACTT-3' (1492R) for reverse sequencing. 16S rRNA sequences were deposited to Genbank database to get the accession number and most similar sequence alignment using www.ncbi.nlm.gov/BLAST ${ }^{12}$ was identified. the nucleotide sequences were aligned with MUSCLE and phylogentic tree was constructed with the help of MEGA 5.2 software.I

\section{Biosorbent preparation:-}

All the strains were inoculated separately into $100 \mathrm{~mL}$ nutrient broth in $500 \mathrm{~mL}$ conical flasks and incubated on a shaker at $150 \mathrm{rpm}$ for $24 \mathrm{~h}$ at $28^{\circ} \mathrm{C}$. The cells were grown to late exponential phase, harvested by centrifugation (REMI, India) at 10,000 rpm for $30 \mathrm{~min}$ at $4^{\circ} \mathrm{C}$ and washed three times with deionized water. Cell suspensions for assay of biosorption potential of live bacteria were prepared by resuspending the cell pellet in deionized water. Biomass concentration in cell suspensions were determined by drying an aliquot in a preweighed aluminum foil container to a constant weight at $80^{\circ} \mathrm{C}^{13}$

\section{Biosorption experiment:-}

Dried and powdered living biomass $(10.0 \mathrm{mg} \pm 0.1)$ of four isolates was inoculated separately into $100 \mathrm{~mL}$ of metal solution containing 25 to $400 \mathrm{ppm}$ of $\mathrm{Ni}, \mathrm{Cr}, \mathrm{Zn}$ and $\mathrm{Pb}$. Metal-free and biosorbent-free solutions were prepared as controls. The flasks $\left(250 \mathrm{~mL}\right.$ ) were kept on rotatory shaker for $24 \mathrm{~h}$ at $30^{\circ} \mathrm{C}$ and $150 \mathrm{rpm}$. After $24 \mathrm{~h}$, cells were harvested from the medium and content of supernatant were analyzed after proper digestion and dilution by AAS. The optimum $\mathrm{pH}$ and temperature were maintained for the growth of microorganisms in batch culture ${ }^{14}$

Biosorption capacity i.e. amount of metal ion $(\mathrm{mg})$ bioabsorbed/g of dried biomass was calculated using the following equation: 
$\mathrm{Q}=((\mathrm{Ci}-\mathrm{Cf}) \mathrm{V}) / \mathrm{m}$

Whereas $\mathrm{Q}=\mathrm{mg}$ of metal ions uptake per gram biomass $(\mathrm{mg} / \mathrm{g}), \mathrm{Ci}$ is initial concentration of metallic ions $(\mathrm{mg} / \mathrm{L})$; $\mathrm{m}$ is dried mass of biosorbent in the reaction mixture $(\mathrm{g})$ and $\mathrm{V}$ is volume of reaction mixture $(\mathrm{mL})$.

\section{Results and Discussion:-}

Heavy metal concentration:-

Heavy metal content of wastewater sample was analysed by AAS. Wastewater samples were highly contaminated with Chromium and Lead metal. The concentration of chromium in DI sample was found $41.16 \pm 0.4 \mathrm{ppm}$. Cobalt and copper were not detectable in BI and OD sample as it showed low level of contamination by industries.

\section{Screening and Minimum Inhibitory concentration of Bacteria:-}

After serial dilution of soil sample, bacterial isolates were selected based on colony morphology and color. These isolates were further purified by streaking separately on nutrient agar plates. Isolated bacteria were further screened for resistance against heavy metals. Among ten isolates only two bacterial strains were selected for Biosorption and minimum inhibitory concentration were determined. These isolates were named as BIN and BOD. The minimum inhibitory concentration (MIC) of bacterial isolates has been depicted in Table 2. MIC range of isolates against various metal concentrations was in the range of $25 \mathrm{mg} / \mathrm{g}$ to $400 \mathrm{mg} / \mathrm{g}$. MIC was found species specific and metal dependent.

\section{Identification:-}

The selected two bacterial isolates were positive to some biochemical tests (Table 3). Based on these biochemical tests and Bergey"s manual of bacteriology ${ }^{15}$, isolates were identified as Pseudomonas sp.

\section{Biosorption experiment:-}

The biosorption potential and percentage removal of heavy metal by Pseudomonas geniculate (BIN) and Pseudomonas hibiscicola (BOD) were shown in table $3 \& 4$. Percentage removal was also represented in figure 32 \& 33. The order of biosorption potential of $\mathrm{BIN}$ and $\mathrm{BOD}$ was $\mathrm{Pb}>\mathrm{Cr}>\mathrm{Zn}>\mathrm{Ni}$ and $\mathrm{Cr}>\mathrm{Pb}>\mathrm{Ni}>\mathrm{Zn}$ respectively. The maximum Biosorption by BIN was observed in Pb i.e., $13.03 \pm 0.47 \mathrm{mg} / \mathrm{g}, 29.7 \pm 0.33 \mathrm{mg} / \mathrm{g}$ and $56.96 \pm 0.18 \mathrm{mg} / \mathrm{g}$ at initial concentration 25,50 , and $100 \mathrm{ppm}$ respectively whereas minimum biosorption potential was observed in Nickel metal i.e., $9.43 \pm 0.31 \mathrm{mg} / \mathrm{g}, 19.5 \pm 0.20 \mathrm{mg} / \mathrm{g}$ and $32.1 \pm 0.03$ at initial concentration 25,50 and $100 \mathrm{ppm}$ respectively. The maximum percentage removal was observed $59.9 \%$ at $50 \mathrm{ppm}$ initial concentration of $\mathrm{Pb}$ metal and the minimum percentage removal was observed $32.1 \%$ at $100 \mathrm{ppm}$ of Ni. For BOD, the maximum biosorption potential of Pseudomonas hibiscicola showed for Chromium i.e., $12.3 \pm 0.66 \mathrm{mg} / \mathrm{g} \& 30.2 \pm 0.08 \mathrm{mg} / \mathrm{g}$ at $25 \& 50$ ppm; Lead was $60.8 \pm 0.47 \mathrm{mg} / \mathrm{g}$ at $100 \mathrm{ppm}$ and Zinc was $100.4 \pm 0.52 \mathrm{mg} / \mathrm{g} \& 121.03 \pm 0.54 \mathrm{mg} / \mathrm{g}$ at $200 \& 400$ $\mathrm{ppm}$.The percentage removal of $\mathrm{Pb}, \mathrm{Zn}, \mathrm{Cr}$ and $\mathrm{Ni}$ by Pseudomonas hibiscicola represented in figure 26 . The percentage removal by Pseudomonas hibiscicola of lead was 46.6\%, 55.2\% \& 60.8\%; Zinc was 37.33\%, 47.33\% $58.9 \%, 50.2 \% \& 30.2 \%$; Chromium was $49.33 \%, 60.46 \% \& 54.1 \%$ and $53.4 \%, 50.8 \%, 33.43 \% 36.58 \%$ and $35.87 \%$ at $25,50,100,200 \& 400 \mathrm{ppm}$ respectively.

Table 1:-Metal concentration in wastewater samples (In ppm)

\begin{tabular}{|l|l|l|l|l|}
\hline Metals & HI & BI & OD & DI \\
\hline $\mathrm{Cr}(\mathrm{ppm})$ & $16.2 \pm 0.3$ & $14.5 \pm 0.19$ & $9.85 \pm 0.06$ & $41.16 \pm 0.4$ \\
\hline $\mathrm{Pb}(\mathrm{ppm})$ & $26.8 \pm 0.14$ & $20 \pm 0.18$ & $17.8 \pm 0.3$ & $26.8 \pm 0.7$ \\
\hline $\mathrm{Ni}(\mathrm{ppm})$ & $6.35 \pm 0.17$ & $2.03 \pm 0.16$ & $0.17 \pm 0.02$ & $8.4 \pm 0.1$ \\
\hline $\mathrm{Zn}(\mathrm{ppm})$ & $4.16 \pm 0.02$ & $3.79 \pm 0.2$ & $1.8 \pm 0.01$ & $14.25 \pm 0.08$ \\
\hline $\mathrm{Co}$ & $1.5 \pm 0.69$ & $2.83 \pm 0.02$ & $\mathrm{ND}$ & $3.10 \pm 0.003$ \\
\hline $\mathrm{Cu}$ & $3.5 \pm 0.06$ & $2.9 \pm 0.008$ & $\mathrm{ND}$ & $3.3 \pm 0.16$ \\
\hline $\mathrm{Cd}$ & $0.155 \pm 0.006$ & $\mathrm{ND}$ & $0.01 \pm 0$ & $1.5 \pm 0.03$ \\
\hline $\mathrm{Fe}$ & $1.5 \pm 0.2$ & $2.38 \pm 0.09$ & $0.9 \pm 0$ & $2.8 \pm 0.02$ \\
\hline
\end{tabular}


Table 2:- Minimum inhibition concentration of four isolates $\left(,{ }^{+++}+{ }^{e c}\right.$ is $75 \%$ inhibition, , $++^{+e}$ is $50 \%$ inhibition, , $+^{\text {e }}$ is $25 \%$ inhibition, ,-, , is no inhibition).

\begin{tabular}{|c|c|c|c|}
\hline Metals & Initial concentration & BIN & BOD \\
\hline \multirow{5}{*}{$\mathbf{P b}$} & 25 & +++ & + \\
\hline & 50 & +++ & + \\
\hline & 100 & +++ & + \\
\hline & 200 & - & - \\
\hline & 400 & - & - \\
\hline \multirow{5}{*}{ Zn } & 25 & +++ & + \\
\hline & 50 & ++ & + \\
\hline & 100 & - & + \\
\hline & 200 & - & + \\
\hline & 400 & - & + \\
\hline \multirow{6}{*}{$\mathrm{Cr}$} & & & \\
\hline & 25 & ++ & ++ \\
\hline & 50 & ++ & + \\
\hline & 100 & + & - \\
\hline & 200 & - & - \\
\hline & 400 & - & - \\
\hline \multirow{6}{*}{$\mathbf{N i}$} & & & \\
\hline & 25 & ++ & + \\
\hline & 50 & + & + \\
\hline & 100 & + & \\
\hline & 200 & - & + \\
\hline & 400 & - & + \\
\hline
\end{tabular}

Table 3:- Identification of isolates

\begin{tabular}{|l|l|l|}
\hline Test & B(IN) & $\mathbf{B}(\mathbf{O D})$ \\
\hline Indole & - & - \\
\hline Methy-Red & - & - \\
\hline Voges-proskauer & + & + \\
\hline Citrate Utilisation & - & - \\
\hline Gas production from glucose & - & - \\
\hline Starch hydrolysis & - & - \\
\hline Nitrate Reduction & - & - \\
\hline Catalase test & + & + \\
\hline Oxidase & + & - \\
\hline Urea hydrolysis & + & + \\
\hline
\end{tabular}

Table 4:-Biosorption potential and percentage removal of heavy metal $(\mathrm{Pb}, \mathrm{Zn}, \mathrm{Cr} \& \mathrm{Ni})$ by Pseudomonas geniculate (BIN)

\begin{tabular}{|c|c|c|c|c|c|c|c|c|}
\hline $\begin{array}{l}\text { Initial } \\
\text { concentratio } \\
\mathrm{n}\end{array}$ & $\begin{array}{l}\text { Biosorptio } \\
\mathrm{n} \text { potential } \\
(\mathrm{mg} / \mathrm{g})\end{array}$ & $\begin{array}{l}\% \\
\text { Removal }\end{array}$ & $\begin{array}{l}\text { Biosorptio } \\
\mathrm{n} \text { potential } \\
(\mathrm{mg} / \mathrm{g})\end{array}$ & $\begin{array}{l}\% \\
\text { Removal }\end{array}$ & $\begin{array}{l}\text { Biosorptio } \\
\mathrm{n} \text { potential } \\
(\mathrm{mg} / \mathrm{g})\end{array}$ & $\begin{array}{l}\% \\
\text { Removal }\end{array}$ & $\begin{array}{l}\text { Biosorptio } \\
\mathrm{n} \text { potential } \\
(\mathrm{mg} / \mathrm{g})\end{array}$ & $\begin{array}{l}\% \\
\text { removal }\end{array}$ \\
\hline & $\mathrm{Pb}$ & $\mathrm{Pb}$ & $\mathrm{Zn}$ & $\mathrm{Zn}$ & $\mathrm{Cr}$ & $\mathrm{Cr}$ & $\mathrm{Ni}$ & $\mathrm{Ni}$ \\
\hline $25 \mathrm{ppm}$ & $\begin{array}{l}13.03 \pm \\
0.47\end{array}$ & $\begin{array}{r}52.1333 \\
3\end{array}$ & $13.6 \pm 0.5$ & 54.4 & $11.1 \pm 0.51$ & $\begin{array}{r}44.5333 \\
3 \\
\end{array}$ & $9.43 \pm 0.31$ & $\begin{array}{r}37.7333 \\
3 \\
\end{array}$ \\
\hline $50 \mathrm{ppm}$ & $29.7 \pm 0.33$ & $\begin{array}{r}59.5333 \\
3\end{array}$ & $28.4 \pm 0.81$ & $\begin{array}{r}56.9333 \\
3\end{array}$ & $25.9 \pm 0.41$ & $\begin{array}{r}51.8666 \\
7\end{array}$ & $19.5 \pm 0.20$ & 39 \\
\hline $100 \mathrm{ppm}$ & $\begin{array}{l}56.96 \pm \\
0.18 \\
\end{array}$ & $\begin{array}{r}56.9666 \\
7 \\
\end{array}$ & - & 0 & $\begin{array}{l}36.83 \pm \\
1.68 \\
\end{array}$ & $\begin{array}{r}36.8333 \\
3 \\
\end{array}$ & $32.1 \pm 0.06$ & $\begin{array}{r}32.1666 \\
7 \\
\end{array}$ \\
\hline $200 \mathrm{ppm}$ & - & 0 & - & 0 & - & 0 & - & 0 \\
\hline $400 \mathrm{ppm}$ & - & 0 & - & 0 & - & 0 & - & 0 \\
\hline
\end{tabular}


Table 5:-Biosorption potential and percentage removal of heavy metal $(\mathrm{Pb}, \mathrm{Zn}, \mathrm{Cr} \& \mathrm{Ni})$ by Pseudomonas hibiscicola (BOD)

\begin{tabular}{|c|c|c|c|c|c|c|c|c|}
\hline $\begin{array}{l}\text { Initial } \\
\text { concentratio } \\
\mathrm{n}\end{array}$ & $\begin{array}{l}\text { Biosorptio } \\
\mathrm{n} \text { potential } \\
(\mathrm{mg} / \mathrm{g})\end{array}$ & $\begin{array}{l}\% \\
\text { Removal }\end{array}$ & $\begin{array}{l}\text { Biosorptio } \\
\text { n potential } \\
(\mathrm{mg} / \mathrm{g})\end{array}$ & $\begin{array}{l}\% \\
\text { Removal }\end{array}$ & $\begin{array}{l}\text { Biosorptio } \\
\mathrm{n} \text { potential } \\
(\mathrm{mg} / \mathrm{g})\end{array}$ & $\begin{array}{l}\% \\
\text { Removal }\end{array}$ & $\begin{array}{l}\text { Biosorptio } \\
\mathrm{n} \text { potential } \\
(\mathrm{mg} / \mathrm{g})\end{array}$ & $\begin{array}{l}\% \\
\text { removal }\end{array}$ \\
\hline & $\mathrm{Pb}$ & $\mathrm{Pb}$ & $\mathrm{Zn}$ & $\mathrm{Zn}$ & $\mathrm{Cr}$ & $\mathrm{Cr}$ & $\mathrm{Ni}$ & $\mathrm{Ni}$ \\
\hline $25 \mathrm{ppm}$ & $\begin{array}{l}11.66 \pm \\
0.33\end{array}$ & $\begin{array}{r}46.6666 \\
7\end{array}$ & $9.33 \pm 0.33$ & $\begin{array}{r}37.3333 \\
3\end{array}$ & $12.3 \pm 0.66$ & $\begin{array}{r}49.3333 \\
3\end{array}$ & $13.3 \pm 0.86$ & $\begin{array}{r}53.4666 \\
7\end{array}$ \\
\hline $50 \mathrm{ppm}$ & $27.6 \pm 0.11$ & 55.2 & $\begin{array}{l}23.66 \pm \\
0.17\end{array}$ & $\begin{array}{r}47.3333 \\
3\end{array}$ & $30.2 \pm 0.08$ & $\begin{array}{r}60.4666 \\
7\end{array}$ & $25.4 \pm 0.15$ & 50.8 \\
\hline $100 \mathrm{ppm}$ & $60.8 \pm 0.47$ & $\begin{array}{r}60.8333 \\
3\end{array}$ & $58.9 \pm 0.52$ & $\begin{array}{r}58.9333 \\
3\end{array}$ & $54.1 \pm 1.0$ & 54.1 & $33.4 \pm 1.20$ & $\begin{array}{r}33.4333 \\
3\end{array}$ \\
\hline $200 \mathrm{ppm}$ & - & 0 & $\begin{array}{l}100.4 \pm \\
0.52\end{array}$ & 50.2 & - & 0 & $\begin{array}{l}73.16 \pm \\
1.49\end{array}$ & $\begin{array}{r}36.5833 \\
3\end{array}$ \\
\hline $400 \mathrm{ppm}$ & - & 0 & $\begin{array}{l}121.03 \pm \\
0.54\end{array}$ & $\begin{array}{r}30.2583 \\
3\end{array}$ & - & 0 & $\begin{array}{l}143.5 \pm \\
1.32\end{array}$ & 35.875 \\
\hline
\end{tabular}

Figure 1:- Phylogenetic tree of BIN

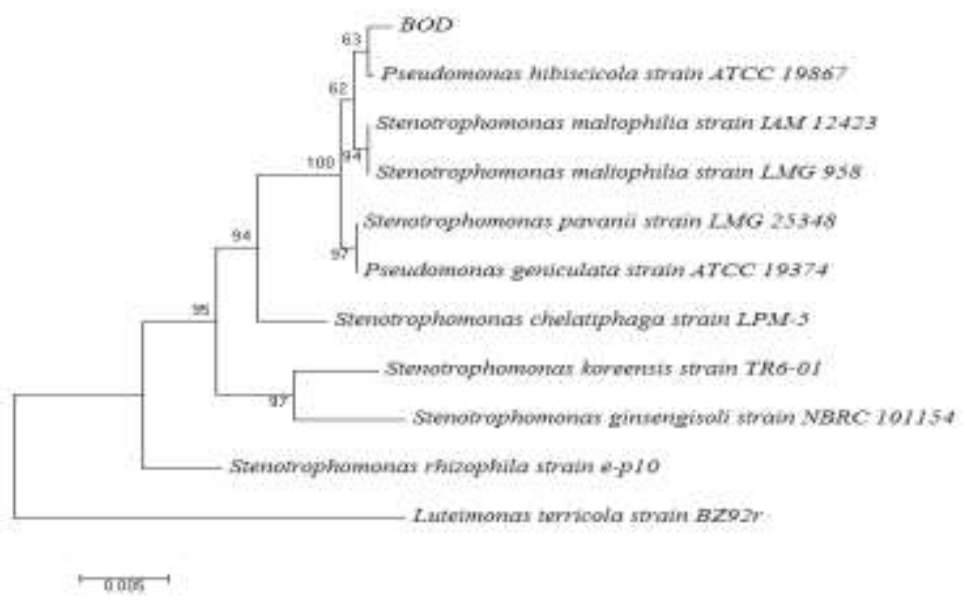

Figure 2 :- Phylogenetic tree of BOD

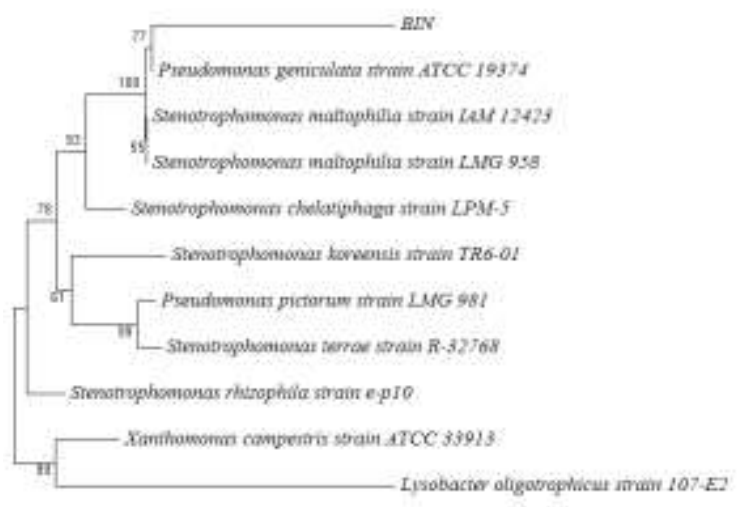


Figure 3:- Percentage removal by BIN

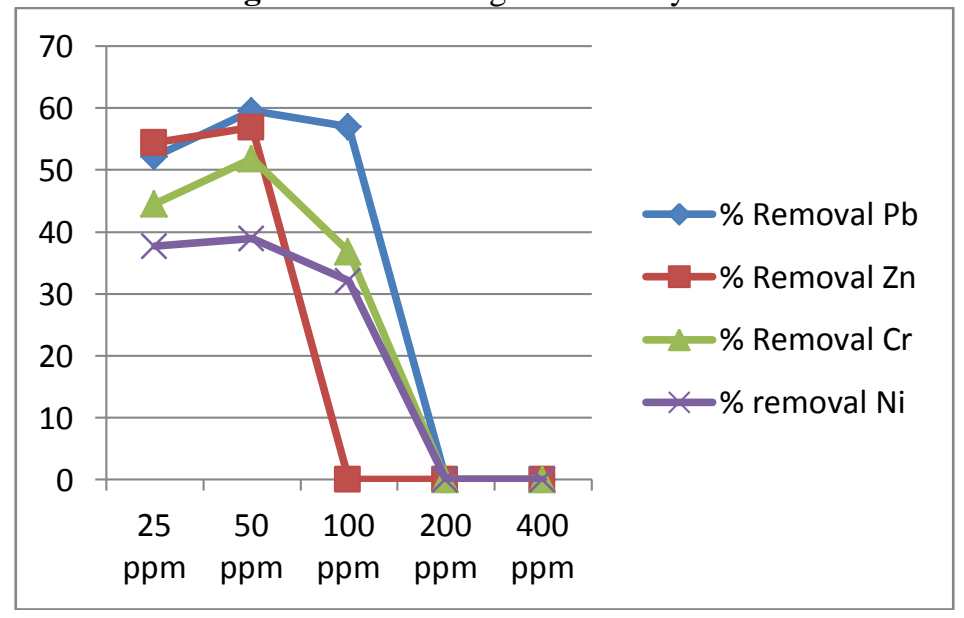

Figure 4 :-Percentage removal byBOD

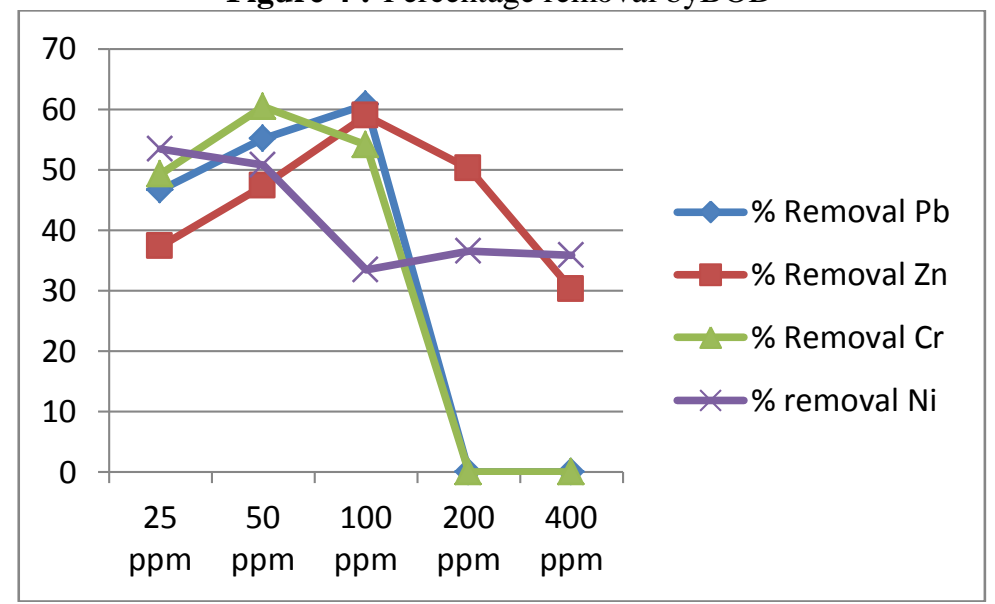

\section{References:-}

1. Mulligan, C. N., Yong, R. N. and Gibbs, B. F. (2001). Remediation technologies for metal-contaminated soil and groundwater: an evaluation. Engin. Geol, 60: 193-207.

2. Anderson, D. (2003). Introduction to heavy metal monitoring, European Environment Agency (EPA), environment assessment report no. 10, Europe's environmental :- the $3^{\text {rd }}$ assessment,published on web by Epa.

3. Shayley H., Mcbride M, and Harrison E. (2009). Sources and impacts of contamination in soils. Cornell waste management Institute. 1-6.

4. Fostner, U. and Wittmann, GTW (1983). Metal pollution in the aquatic environment Gremany: Springer- Verlag Berlin Heidelberg.

5. - Hussien, H., Farag, S. and Moawad, H. (2003). Isolation and characterization of Pseudomonas resistant to heavy metals contaminants. Arab Journal of Biotechnology. 7: 13-22.

6. Volesky, B., 1990. Biosorption of Heavy metals. Biotechnology Progress. 11, 235-250.

7. Analya, N., Ramachandra, T. V., KANAmadi, R. D., (2003). Biosorption of Heavy metals. Res. Journal of Chem. Env.7, 4:71-70. ISSN 0972-0626.

8. APHA

9. Aneja, K. R.(2010).In: Experiments in microbiology, plant pathology and biotechnology (4th edition ). New age international (pvt) ltd., New Delhi.

10. 16. Hansson, P.J.; Edwards, N.T. and Andrews, J.A. (2003).Effect of different tree species on soil properties.Journal of Applied Ecology.23: 657-666.

11. 17. Sam brook J, Fritsch EF, ManiatisT(1989) Molecular cloning: a laboratory manual (2nd edn), cold spring harbour, New York. 
12. Tamura K., Peterson D., Peterson N., Stecher G., Nei M., and Kumar S. (2011). MEGA5: Molecular Evolutionary Genetics Analysis using Maximum Likelihood, Evolutionary Distance, and Maximum Parsimony Methods. Molecular Biology and Evolution 28: 2731-2739.

13. Puranik, P. R. and Paknikar, K. M. (1999): Biosorption of lead, cadmium and zinc by Citrobacter strain MCM B-181: characterization studies. Biotechnol. Prog., 15: 228-237.

14. Cybulski Z, Dzuirla E, Kaczorek E, Olszanowski A, (2003). The influence of emulsifiers on hydrocarbon biodegradation by pseudomonadacea and Bacillacea strains. Spill Science and technology bulletin 8:503-507

15. John G H; Noel R K; Peter H A S; James T S and Stanley T W.(1994) Bergey 's manual of Determinative Bacteriology (9th edition). Lippincott Williams \& Wilkins, New York. 